\title{
In-Service EFL Teachers' Attitudes towards the Communicative Approach and their Perceptions of the Constraints Acting Against its Success
}

\section{Dr. Jamal Hamed Jahin}

\section{ABSTRACT}

This study aimed to assess in-service EFL teachers' attitudes towards the communicative approach in language teaching and learning. It also aimed to ascertain their perceptions of the constraints that act against the successful use of the communicative pedagogy in teaching English as a foreign language.

Data were collected by using two research instruments. The first is the Teachers' Attitudes towards the Communicative Approach Scale (TACAS) which was designed for the purpose of the study and aimed to ascertain in-service EFL teachers' attitudes towards the communicative approach versus the form-based structural view of language teaching and learning. The scale consisted of 26 statements representing 10 thematic units, which stand for facets of clash between the communicative pedagogy and form-based pedagogy. The TACAS was administered to a sample of 120 in-service EFL teachers at 17 preparatory schools. The second instrument was a semi-structured interview that was conducted to a sample of 15 teachers taken from the TACAS sample. The semi-structured interviews aimed to ascertain in-service EFL teachers' perceptions of the constraints that hamper the feasibility of the communicative approach in their school contexts. The reliability and validity of data collection instruments were assessed. The quantitative TACAS data were analyzed by using SPSS software. Both descriptive and inferential statistical techniques were used. The qualitative data were analyzed by using the grounded theory approach to qualitative data analysis.

The findings of the TACAS analysis indicated that the majority ( $\mathrm{n} .70=$ $58.33 \%$ ) of the teachers tend to hold mildly favourable to favourable attitudes towards the communicative view of language teaching and learning. Besides, findings reflected differences between teachers due to specialization, teaching experience and training. Specialist and less-experienced teachers were more inclined to favour the communicative view of language teaching and learning than nonspecialist and experienced teachers. Likewise, trained teachers favoured to use audio visual materials, as a source of authentic target language input than untrained teachers did. Findings of interview analysis indicated that two types of constraints acted against teachers' application of communicative classroom activities: extrinsic and intrinsic constraints.

The study highlights the strong impact of the social and cultural context upon teachers' attitudes and their perceptions of the constraints that impede a successful implementation of the commu- nicative approach. Implications related to EFL curriculum innovation and teacher education are discussed.

Keywords: In-service EFL teachers' attitudes, the communicative approach and constraints 


\section{Introduction}

Foreign language learning in Egypt has a long history and is intimately connected with Egypt's own social and economic history. With the open door policy brought in by President Sadat, interest in learning English increased. The imperative to learn English was strengthened by the introduction of English to the first grade primary. This was triggered by the realization of the economic and political importance of English in the world. However, the national imperative to learn English has been hampered by both a poor supply of suitably qualified teachers, often lacking proficiency in English, and poor school and classroom conditions. Since 1988, attention has been directed to teaching materials based on the communicative approach but less attention has been paid to providing teachers with the necessary skills and understanding for teaching English. Since 1991, the government has been pursuing a policy aiming to improve the education service (Baha Eddin, 1991) through sending cohorts of teachers to the USA and United Kingdom (Johnson et al., 2000) for training. Additionally, in-service teacher training centres have introduced teachers to new teaching methods. Despite all the efforts, however, the focus has always been on teachers' behaviours, rather than on their attitudes and beliefs.

\section{The Communicative Approach}

The communicative approach in language teaching originates from a theory of language as communication. According to this approach, the main objective of language teaching is to develop what Hymes (1972) referred to as "communicative competence". The communicative approach remains the favoured methodological approach in ESL/EFL teaching (Anderson, 1993), and is supported by modern

\section{4}

J ournal of Arabic Studies in Education \& Psychology ( ASEP ) 
theories of learning and teaching. The Egyptian ELT context has for long been a traditional, structurally-oriented , foreign language teaching contexts where knowledge about language form is much more important than the ability to use language meaningfully, or functionally.New curricula were developed with the communicative approach as a philosophy . The recommendations of the National Conferences for Developing Primary and Preparatory Education (1993 and 1996) place emphasis on the implementation of the communicative approach.

\section{Curriculum Innovation}

Proponents of the communicative approach regarded the communicative approach as an innovation with many specific characteristics. The communicative approach views language as a tool for communication. It insists that interactional speaking activities in classrooms be instances of real communication. It ensures that students have sufficient exposure to the target language . Therefore, application of the communicative approach in Egyptian EFL classrooms would bring a positive effect on EFL teaching and learning process. Since the communicative approach is underpinned by a set of beliefs and principles, it matches Markee's (1997:53) model of primary curriculum innovation . By primary innovation, is meant change with respect to three dimensions:(1)teaching materials; (2) methodological skills and; (3) pedagogical values (see fig. 1 below), which constitute the core dimensions of teaching and learning (Fullan, 1993). Change in one dimension necessitates change in the other two dimensions. There is a reciprocal interaction between the three dimensions of curriculum innovation. This relationship is complex due to the

\section{5}

Journal of Arabic Studies in Education \& Psychology ( ASEP ) 
unsettled debate as to whether change in teaching materials and methodological skills leads to change in pedagogical values or vice versa, or whether change in both occurs simultaneously (Markee, 1997 and Richardson, 1996). Fullan (1993) observes that, in practice, empirical evidence suggests that pedagogical values or beliefs may change as a result of experience. To resolve this debate, he concludes: 'perhaps it is sufficient for our purposes to recognize that the relationship between beliefs and behaviour is reciprocal trying new practices sometimes leads to questioning one's underlying beliefs; examining one's beliefs can lead to attempting new behaviour'. This reciprocity between beliefs and behaviour is depicted in Figure (1) below as the 'innovation triangle' (Markee, 1994).

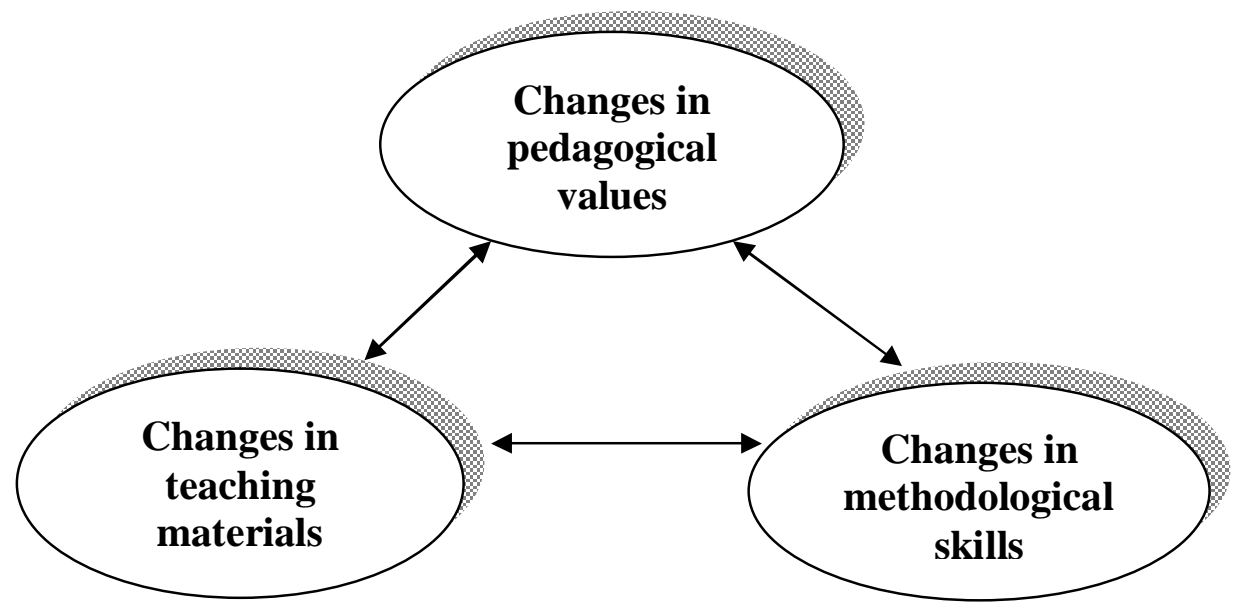

Figure (1): The Dimensions of Primary Curriculum Innovation (Markee 1997:54)

\section{The Ecology of Curriculum Innovation in Egypt}

In the Egyptian ELT context, change in teaching materials in the form of new textbooks and change in teaching approaches advocated by the Ministry of Education

\section{6}

\section{J ournal of Arabic Studies in Education \& Psychology ( ASEP )}


(MOE) have not been paralleled by any attempt to achieve a change in the pedagogical values of the teachers involved. Teaching materials are often given priority, with large sums of money spent on developing EFL school textbooks with the help of foreign expertise. In-service training has, for a long time, focused on the "teaching methods notion". Teacher training is often short-term and aims to infuse teachers with prescriptive teaching ideals. Moreover, these programmes do not attempt to explore teachers' knowledge and beliefs about teaching and learning, or to take account of the context in which teachers operate. Training makes no reference to the constraints that might conflict with the philosophy of the teaching materials. Frequently, teachers feel a wide gap between theory and practice, which is attributable to a lack of consideration of two levels of context: firstly, the outer social context, and secondly, the inner context which includes teachers' and students' attitudes. We can argue that the cycle of curriculum innovation is incomplete, because changes in methodologies and materials are not coupled with an attempt to achieve a parallel change in pedagogical values. The individual end users' subjective perceptions of newness, which are the most influential agent that determines whether an approach to organizing language instruction counts as innovation, are not taken into account. Teachers' knowledge and beliefs shape the sense they make of any educational innovation, and play a critical role in how they behave in the classroom situation (Topper, 1999). Hence, the attempt of this study is to explore teachers' attitudes towards the communicative approach as a curriculum innovation and explore the range of constraints facing teachers in general and the communicative approach in particular.

\section{7}

Journal of Arabic Studies in Education \& Psychology ( ASEP ) 


\section{Research Questions}

This study seeks to find answers to the following research questions:

1. What are EFL teachers' attitudes towards the communicative approach in language teaching and learning?

2. What are the constraints that act against a successful application of the communicative approach in the Egyptian EFL context?

\section{Objectives of the Study}

In accordance with the research questions, this study aims to

1. explore Egyptian EFL teachers' attitudes towards the communicative approach.

2. identify the constraints that act against a successful application of the communicative approach in the Egyptian EFL context.

3. probe the feasibility of the communicative approach in the Egyptian school context.

\section{Significance of the Study}

The significance of the study can be represented through the following:

1. The study provides insight for EFL teacher educators ${ }^{1}$ to attend to the role that teachers' attitudes and theories play in handling an innovation in curricula since trainees' attitudes have the ability to filter this innovation.

${ }^{1}$ In this study 'teacher educators' are understood as those responsible for training teachers at both pre-service and in-service levels.

\section{8}

J ournal of Arabic Studies in Education \& Psychology ( ASEP ) 
2. Giving room to in-service teachers to uncover the constraints facing them encourages teacher trainers to provide training that is workable and touches teachers' reality.

3. This study's focus on the cognitive aspects of EFL teachers' lives enables teacher educators to know the most appropriate support they can provide for inservice professional development for EFL teachers (Breen, 1991).

4. The study tries to add to the research literature related to the feasibility of the communicative approach and the circumstances surrounding its application.

5. Identifying the range of mediating factors that affect how EFL teachers act upon their beliefs, the study aims to question and uncover the 'always taken-forgranted-and untouchable ELT context' and the constraints based in it.

6. The study tries to attract the attention of ELT curriculum developers and syllabus designers to see how far their products can be assimilated or not. This helps to close the gap between the producers of teaching materials and their users.

7. The study's use of the interpretive-constructivist research framework to explore teachers' constructs would encourage other teacher-related research to make use of it.

\section{Design of the Study}

Since the aim is to come to grips with how reality is seen through the teachers' eyes, how teachers construe reality, view their world and make sense of it (Walsh et al. 1993), the interpretative-constructivist research paradigm was adopted. The purpose of the study was to explore Egyptian EFL teachers' attitudes towards the communic-

\section{9}

Journal of Arabic Studies in Education \& Psychology ( ASEP ) 
ative approach, in the light of their personal histories and the contextual constraints they face. Thus, in the context of this study, teachers are understood from the constructivist perspective to be meaning-making organisms, theory builders who develop hypotheses, notice patterns, and construct theories of action from their life experiences (White \& Gunstone, 1992).

The methods used to collect and analyze the data in this study are based on the principles of qualitative field studies (Bogdan and Belken, 1992; Goetz and Le Compte, 1984; Miles and Huberman, 1994; etc.). Coinciding with this, data collection was conducted using two types of instruments: (1) Teachers' Attitudes towards the Communicative Approach Scale (TACAS) and (2) semistructured interviews.

\section{Variables of the Study}

Participants of the study differed in terms of a number of variables, namely, gender, age, qualification or major, teaching experience and in-service training. In addition to teachers' overall attitudes toward the communicative approach and the amount they practice the approach, the researcher was keen on finding out if any of these variables would affect teachers' views toward the communicative approach. Thus, they were included in the analysis.

\section{Data Collection and Sampling}

Data collection went through two phases, as illustrated below

Phase1:Teachers' Attitudes towards the Communicative Approach Scale

The Teachers' Attitudes towards the Communicative Approach Scale (TACAS) was designed for the purpose of

\section{0}

Journal of Arabic Studies in Education \& Psychology ( ASEP ) 
the study. It aims to explore EFL teachers' attitudes to the communicative approach as an innovation versus the traditional form-oriented structural notion in language teaching and learning. The TACAS consists of 26 items constituting ten thematic units and representing aspects that contrast between the communicative view of language teaching and learning versus the form-based structural view of language teaching and learning. The set of 26 items consists of 13 positive and 13 negative items reflecting aspects of two opposite traditions. The positive items represent the communicative view of language teaching and learning while the negative items represent the form-based or structural view of language teaching and learning. The 26 statements are matched against a five-point Likert scale ranging from strongly agree (SA) to strongly disagree (SD) (see Appendix 1). A numerical value was given to the response made to each statement. Values were reversed for positively and negatively worded statements. Positive statements are those statements that represent the communicatively-oriented view of language teaching and learning, whereas negative statements represent the formoriented structural view of language teaching and learning.

Development of the items of the TACAS was based on three considerations: (1) review of related literature (see Freeman, 1986; Harmer, 1986; Johnson and Morrow, 1981; Littlewood, 1981; Nunan, 1989; Richards and Rodgers, 1986; etc.); (2) review of previously designed scales for similar purposes (Cook, 1991; Horwitz, 1986; Johnson, 1992; and Karavas-Doukas, 1993 \& 1996); and (3) workability of the instrument for the target sample.

To assess the face validity of the TACAS, it was handed to a number of 19 ELT university staff members

\section{1}

J ournal of Arabic Studies in Education \& Psychology ( ASEP ) 
both in Egypt and abroad. ${ }^{2}$ The jury gave invaluable feedback related to the wording of the items and the readability of each item. The feedback collected led to rewording, replacing, deleting and, sometimes, adding items.

Realizing that the communicative approach has a variety of syllabus realizations, effort was made to develop items that reflect the version adopted by the Egyptian English language syllabus, and textbooks. Thus, the teachers' guides to the textbooks proved invaluable in the construction of the statements, some of which were composed based on the writings of communicative methodologists (Brumfit \& Johnson, 1979; Brumfit, 1984 \& 1985; Harmer, 1997; Littlewood, 1981; Nunan, 1989a \& 1989b; 1995a \& 1995b; and Richards and Rodgers, 2006; etc.). In general, effort was made to ensure that the statements fell within the respondents' frame of reference. Statements were put in a behavioural fashion (i.e., representing classroom activities) for respondents to understand easily. This is based on the argument that teachers' conceptions of English language teaching are often based on the methodologies they use (Stern, 1983) and that methods are triggered by approaches (Richards and Rodgers, 1986).

The reliability of the TACAS was assessed via the test-retest method. It was administered twice to a sample of in-service EFL teachers taken from a region similar to the

${ }^{2}$ These included 5 Egyptian ELT professors; 5 American and 4 British university tutors working in Taibah University, Saudi Arabia; and 5 British ELT specialists based in the School of Education, University of Exeter, UK.

\section{2}

Journal of Arabic Studies in Education \& Psychology ( ASEP ) 
sample of in-service EFL teachers in the main study. An interval of five weeks separated the two administrations. An Alpha Cronbach correlation coefficient of .92 was calculated.

The TACAS was piloted during the first month of the first term of the school year 2007/2008. The piloting aimed to check the readability of the TACAS items and check the time needed and assess the suitable circumstances for its administration. The TACAS in its final version consisted of two sections. The first was the attitudes scale itself and the second section aimed to collect some background information about the respondents, such as age, gender, qualifications, teaching experience, and in-service training. This information constitutes part of respondents' experiences, which might have had some effect on teachers' beliefs. This is because teachers' beliefs are not context-free (Topper, 1999).

The TACAS was translated into Arabic and translation was crosschecked by two independent professional translators whose majors are English language and linguistics and Languages and translation. The purpose was to make sure that the English version is equal in meaning to the Arabic version.

The questionnaire was personally distributed by the researcher to a random sample of 155 preparatory schoolteachers belonging to 17 preparatory schools based in three educational directorates in urban, suburban, and rural areas. Returned complete copies were 120 representing a response rate of $77.41 \%$. Figure (2) below represents the methodological framework of the study.

\section{3}

J ournal of Arabic Studies in Education \& Psychology ( ASEP ) 
Vol.2 .. No.1.. January 2008

DATA COLLECTION

(1) Phase One

Teachers' Attitudes towards the Communicative Approach Scale (TACAS) SAMPLE $=120$ TEACHERS)

(2) Phase Two

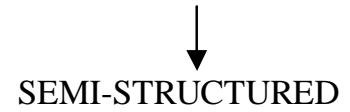

(Sample $=15$ Teachers)

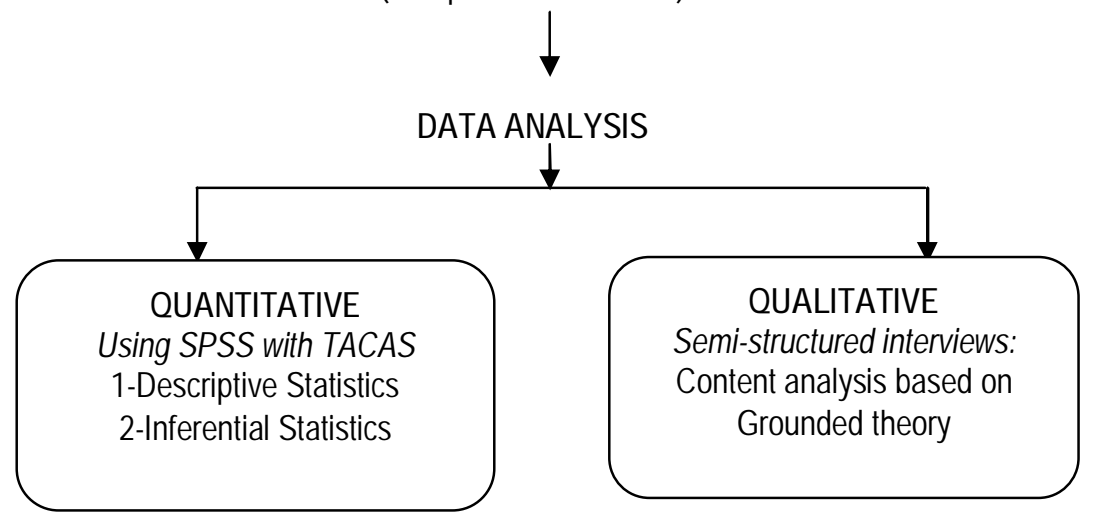

Figure (2): Methodological Framework of the Study

\section{Phase 2: The Semi-Structured Interviews}

The Semi-Structured Interviews aimed to ascertain the range of constraints facing teachers in the teaching of EFL using the communicative approach philosophy. Using an interview is not something common in the Egyptian research context (Cook 1998 and Hargreaves 1997). This explains the small number of teacher interviewees in general and the fact that men teachers outnumber women

\section{4}

\section{J ournal of Arabic Studies in Education \& Psychology ( ASEP )}


teachers (see Appendix 2).

The interview protocol addressed almost all the potential constraints teachers might face as when teaching EFL by using the techniques of the communicative approach. The issues addressed include constraints facing teachers in daily work; constraints facing them in the school/classroom atmosphere; constraints related to teaching materials; constraints related to the perceived gap between the teaching materials and the classroom reality; out-of-school constraints; etc.

Interviews were conducted with fifteen of the TACAS sample. The average interview lasted for one and half hours. Interviews were tape-recorded. Criteria of choosing the fifteen informants at the second phase of the study include willingness to participate; sense of responsiveness; easygoingness; and availability of time. Interviews were conducted in as much informal atmosphere as possible and in a friendly manner. Anonymity of the informants was preserved by using alphabetical letters to refer to them. The purpose was to make informants comfortable so as to voice themselves openly. A profile of informants' background is represented in Table (1) below.

The sample of informants consisted of 10 male teachers and 5 female teachers. As for qualifications, 11 teachers had Bachelor degree in Arts and Education (English) while 4 had Bachelor degree in Arts (English). As for teaching experience, informants varied between newly graduated, to semi-experienced, to experienced. As for school location, informants belonged to three different school locations: urban $(n=8)$, sub-urban $(n=3)$ and rural $(\mathrm{n}=4)$.

\section{5}

J ournal of Arabic Studies in Education \& Psychology ( ASEP ) 
Vol.2 .. No.1.. January 2008

Table (1): Profile of In-service EFL Teachers Interviewees

\begin{tabular}{|c|c|c|c|c|}
\hline Teachers & $\begin{array}{c}\text { Gender } \\
(\mathbf{1 0} \text { male }) \\
\mathbf{( 5} \\
\text { female) }\end{array}$ & Qualifications & $\begin{array}{c}\text { Teaching } \\
\text { Experience } \\
\text { in Years }\end{array}$ & $\begin{array}{c}\text { School } \\
\text { location }\end{array}$ \\
\hline A & Male & BA in Arts and Education & 7 & Urban \\
\hline B & Male & BA in Arts and Education & 7 & Urban \\
\hline C & Male & BA in Arts and Education & 6 & Rural \\
\hline D & Female & BA in Arts and Education & 1 & Urban \\
\hline E & Female & BA in Arts (English) & 15 & Rural \\
\hline F & Female & BA in Arts and Education & 6 & Urban \\
\hline G & Male & BA in Arts and Education & 8 & Urban \\
\hline H & Male & BA in Arts and Education & 17 & Urban \\
\hline I & Male & BA in Arts and Education & 17 & Sub-urban \\
\hline J & Male & BA in Arts and Education & 8 & Sub-urban \\
\hline K & Male & BA in Arts (English) & 15 & Urban \\
\hline L & Male & BA in Arts (English) & 12 & Urban \\
\hline M & Female & BA in Arts and Education & 8 & Rural \\
\hline N & Female & BA in Arts (English) & 11 & Sub-urban \\
\hline O & male & BA in Arts and Education & 13 & Rural \\
\hline
\end{tabular}

\section{Data Analysis}

As for the TACAS, the collected responses were statistically processed by using the SPSS software program (Bryman and Cramer, 2001) - version 10. Both descriptive and inferential statistical procedures were used. As for the semi-structured interviews, the recorded interviews were transcribed, then coded and analyzed following the grounded theory approach (Glasser and Strauss, 1976). Reliability of interview data analysis was checked at two levels: firstly, through the coding of the data and secondly, through the analysis and categorization. Concerning coding, it aimed to ensure that the codes fit into the structure and with one another and that they relate to or are distinct from others in a meaningful way. Check-coding of the transcripts was conducted in two ways: firstly, by doing the coding twice at two different times by the researcher and comparing the codes of the first time to those of the second

\section{6}

\section{J ournal of Arabic Studies in Education \& Psychology (ASEP )}


time; and secondly, by asking a colleague to code the transcripts of two interviews. The first approach gave a reliability coefficient of $97 \%$. For the second approach, a reliability coefficient of $71.9 \%$ was achieved between the researcher's coding and his colleague's coding. This percentage was increased to $97 \%$ through discussion of different codes to make sure that all the codes fit into a structure. Agreement was also achieved on the operational definition of codes.

\section{Previous Studies}

A set of previous studies has addressed teachers' attitudes towards the communicative approach and the constraints that hamper its implementation. These include : Li, 1998; Raharjo, 1988; Karavas-Doukas, 1996; Siahaan, 1998; Mulat, 2003; Butler, 2005; Razmjoo and Riazi, 2006; Abd Al-Magid, 2006; etc. For example, Raharjo's (1988) study in Australia aimed to suggest some ways in which Australian teachers could adapt the currently available materials and textbooks for use in communicative teaching. The study found out that although there are many factors in Australia which would favour the introduction of the communicative approach - such as well - equipped classrooms and small class sizes -, the communicative approach does not appear to have been fully developed. This is partly because of the constraint represented in lack of communicatively - based textbooks and teaching materials On the other hand, Karavas-Doukas' (1996) study of Greek public secondary schools EFL teachers' attitudes to the communicative approach realized that one of the causes of the discrepancy between prescribed theory and classroom practice may be teacher attitudes which are not in consistency with the philosophy underpinning the teaching materials. She administered an attitude scale to a sample of fourteen Greek English language teachers whose classroom practices

\section{7}

\section{J ournal of Arabic Studies in Education \& Psychology ( ASEP )}




\section{Vol.2 .. No.1.. January 2008}

had also been observed. The study discovered that teachers tended to hold moderately favourable to favourable attitudes towards the communicative approach. However, observations of classroom teachers indicated a gap between teachers' espoused attitudes and their classroom practices. She identified a set of constraints that hampered teachers' attempts to follow the communicative approach in their teaching. Likewise, Siahaan (1998) in her study of the perceptions of forty- six teachers of the Junior High and the Senior High Schools on the communicative approach in Irian Jaya province, Indonesia found out that the participants were faced by a set of problems in their attempt to implement the communicative approach.

Mulat's (2003) study aimed to find out secondary school English language teachers' attitudes towards the communicative approach and the possible impediments that may hinder its implementation in the classrooms. A questionnaire consisting of 30 items was distributed to 80 English language teachers in ten government secondary schools that are found in West Gojjam and Bahir Dar Special Zones of Amhara Region, Ethiopia. For in-depth scrutiny of the problems teachers face in implementing CLT, ten teachers (one from each school) were interviewed and subsequently observed while teaching in the classrooms. The findings indicated that teachers generally had mildly favourable (positive) attitudes towards communicative language teaching. They, however, articulated a number of constraints that hamper the effective implement ation of CLT. Butler's (2005) study compared and identified the ways in which local elementary schoolteachers consider classroom activities in English that are 'effective' in their given sociocultural and policy contexts in three countries: South Korea, Japan and Taiwan. Classroom activities in these countries were videotaped and edited. The edited

\section{8}

\section{J ournal of Arabic Studies in Education \& Psychology ( ASEP )}


videotape was shown to elementary schoolteachers in these countries. Teachers were then asked to discuss various aspects of teaching practice and activities in small groups. Among the many issues raised by teachers, was the challenges in employing communicative activities with respect to (1) creating motives and goals that drive communicative activities; (2) identifying developmentally appropriate mediational means; and (3) situating activities in specific contexts. The study found that teachers' challenges were due to a lack of understanding of three factors, including what constitutes 'teaching for communicative purposes', the roles that developmental factors play in EFL learning and teaching, and strategies for harmonizing learning/teaching and context.

Razmjoo and Riazi (2006) explored high school and institute teachers' attitudes toward the communicative approach within the context of Iran and the extent to which the teachers of these two contexts materialize and substantiate their attitudes. A questionnaire consisting of five main factors was administered to 100 male and female high school and institute teachers. Moreover, a classroom observation scheme was used to monitor how well and to what extent teachers practice what they believe. Analysis of the data indicated that high school and institute teachers' attitudes toward the communicative approach were positive, indicating a welcoming atmosphere toward the implementation of the communicative approach. However, only the teachers of institutes practice a quasi-communicative type of approach in their classes.

Abd Al-Magid (2006) attempted to determine the impact of teachers' attitudes on their classroom behaviour and therefore on their implementation of the communicative approach. A descriptive case study was conducted at six

\section{9}

Journal of Arabic Studies in Education \& Psychology ( ASEP ) 
secondary schools in Harare, Zimbabwe (as ESL environment) to determine the effect of 38 O-level English teachers' attitudes on their classroom practice. Quantitative and qualitative data collection instruments, including a questionnaire, an observation instrument and a semistructured interview were used to gauge teachers' attitudes, assessing the extent to which attitudes are reflected in their classroom behaviour, and eliciting teachers' verbalisation of how they conceive of their professional task. The findings show that the effective implementation of the communicative approach was critically dependent on teachers' positive attitudes towards this approach.

The above examples of ELT previous research studies were conducted in different parts of the world but for almost the same purpose. It was to assess the EFL/ESL teachers' attitudes towards the communicative approach, as an innovation swaying the universe starting from the seventies of last century. These studies brought to the surface and attracted the attention of policy makers, syllabus designers, teacher educators and other concerned bodies to teachers' attitudes and beliefs since adoption of an innovation should consider the circumstances it is operating in so that the communicative approach can fit well in the English language teaching/learning context.

The above studies targeted one of the most important issues. It is to explore the extent to which the communicative approach is feasible at certain ELT contexts and the variety of variables that affect its implementation both positively and negatively. Survey of previous studies indicates that every study that addressed the feasibility of the communicative approach is unique since the variables it investigates are localized in the ELT contexts they are conducted in. This highlights the paucity of research studies

\section{0}

Journal of Arabic Studies in Education \& Psychology ( ASEP ) 
on the communicative approach in different parts of the world. In this context, this study's attempt to investigate inservice EFL teachers' attitudes towards the communicative approach and the constraints that hamper its implementation from being a success tries to add a snapshot of the Egyptian profile to the worldwide picture in this respect.

\section{The Findings of the Study}

Presentation of the findings of the study will follow the same order of the research questions.

Research Question no. (1): What are teachers' attitudes towards the communicative approach in language teaching and learning?

Respondents' scores in the Teachers' Attitudes towards the Communicative Approach Scale (TACAS) were placed on a continuum ranging between 66 as the lowest score and 97 as the highest. The middle point of the continuum was 81 . The mean score for the TACAS sample was 81.22 and standard deviation was 5.80.

The scores indicate that the majority $(\mathrm{n} .70=58.33 \%$ ) of the teachers tend to hold mildly favourable to favourable attitudes towards the communicative view of language teaching and learning. However, the respondents were not always internally consistent, sometimes ticking both positive and negative statements. This suggests that their attitudes towards the application of the communicative approach might not have been firmly established. This finding necessitates a deeper look into the reasons why teachers tended to be inconsistent in their responses.

To gain a deeper insight into the variation in inservice teachers' scores in the TACAS, a detailed analysis of the responses in the light of teachers' background variables is addressed in the section below. To assess the

\section{1}

J ournal of Arabic Studies in Education \& Psychology ( ASEP ) 
impact of background variables on teachers' attitudes towards the communicative approach versus the structural form-based view of language teaching and learning, inferential statistical procedures were applied. Analysis indicated that there are no statistically significant differences between the respondents. However, there were some clear differences according to specialization (i.e. specialist teachers and non-specialist teachers), teaching experience and in-service training attendance.

\section{Teachers' Attitudes and Specialization}

Analysis of responses indicated that specialist teachers had more favourable attitudes towards the communicative view of language teaching and learning than their non-specialist counterparts did. Statistical significant differences are based in "use of the mother tongue" and "view of learner errors" (see table 2 below).

Specialist teachers favoured the avoidance of the mother tongue over word-by-word translation into the mother tongue more than their non-specialists did $(\mathrm{p}<.000)$ (item 4). Analysis also showed that specialist teachers tended more to hold a view of "learner errors as natural rather than as evidence of imperfect learning" than their non-specialist counterparts did $(\mathrm{p}<.000)$ (item 8). These results related to holding views consistent with the communicative view of language teaching and learning suggest that specialist teachers would favour the communicative approach techniques in their EFL classrooms more than non-specialists would.

\section{Teachers' Attitudes and Teaching Experience}

The analysis of the TACAS highlighted significant differences based on differing levels of teacher experience ( see table 3 below ), particularly between experienced

\section{2}

Journal of Arabic Studies in Education \& Psychology ( ASEP ) 
Table (2):Differences in Attitudes of In-service EFL Teachers Due to Specialization

\begin{tabular}{|c|c|c|c|c|}
\hline & \multirow{2}{*}{ Thematic Units } & \multicolumn{2}{|c|}{ SPECIALIZATION } & \multirow[b]{2}{*}{$\begin{array}{l}\text { 2-tailed } \\
\text { sig. } \\
(* \mathrm{p}<.01)\end{array}$} \\
\hline & & Specialists & $\begin{array}{l}\text { Non- } \\
\text { specialists }\end{array}$ & \\
\hline 1 & Favouring fluency over accuracy & 60.93 & 59.09 & .804 \\
\hline 2 & $\begin{array}{l}\text { Favouring integration of language skills } \\
\text { over separation. }\end{array}$ & 60.90 & 59.20 & .814 \\
\hline 3 & $\begin{array}{l}\text { Paying equal attention to all language skills } \\
\text { rather than attention only to reading and } \\
\text { writing. }\end{array}$ & 62.20 & 59.91 & .306 \\
\hline 4 & $\begin{array}{l}\text { Favouring avoidance of the mother tongue } \\
\text { over word-by-word translation into the } \\
\text { mother tongue }\end{array}$ & 68.51 & 34.20 & $.000 *$ \\
\hline 5 & $\begin{array}{l}\text { Favouring collaborative activities over } \\
\text { whole class lockstep teaching style }\end{array}$ & 62.88 & 52.68 & .153 \\
\hline 6 & $\begin{array}{l}\text { Holding a view that language should be } \\
\text { learned through functional use rather than } \\
\text { only through mastering its structure and } \\
\text { grammar rules. }\end{array}$ & 60.04 & 62.02 & .780 \\
\hline 7 & $\begin{array}{l}\text { Being selective in the correction of learner } \\
\text { errors rather than correcting all students' } \\
\text { errors }\end{array}$ & 62.58 & 53.68 & .222 \\
\hline 8 & $\begin{array}{l}\text { Holding a view of learner errors as natural } \\
\text { rather than as evidence of imperfect } \\
\text { learning }\end{array}$ & 70.64 & 27.20 & $.000^{*}$ \\
\hline 9 & $\begin{array}{l}\text { Favouring the use of audio visual materials } \\
\text { as source of authentic language input over } \\
\text { avoidance of using audio visual materials. }\end{array}$ & 62.01 & 55.54 & .366 \\
\hline 10 & $\begin{array}{l}\text { Holding a view of instruction as learned- } \\
\text { centred rather than teacher-centred. }\end{array}$ & 61.72 & 56.48 & .473 \\
\hline
\end{tabular}

teachers and their less experienced counterparts. There were no statistically significant differences between newlyqualified teachers and semi-experienced teachers. Newlyqualified teachers were more likely to value fluency over accuracy, use collaborative activities and use audiovisual materials. Since these strategies are consonant with communicative approaches, it may be that recent training has equipped them to feel confident with these strategies. The findings below do suggest that the experienced teachers are the least likely to hold favourable attitudes towards or adopt more communicative teaching strategies. 
On the one hand, this may be because their training was least recent and rooted in a different pedagogical framework. Alternatively, the more experienced teachers may be more firmly convinced of traditional methodologies through experience, and be less willing to change.

\section{Teachers' Attitudes and In-Service Training}

Although in general, there were few differences in beliefs and practices according to attendance at in-service training courses, results (see Table 4 below) did indicate that teachers who attended in-service training were significantly more likely to make use of audio visual materials as a source of authentic language input.

In the light of the above analysis of the TACAS, the overall results highlight the following issues:

1. The effect of training: As an independent variable, inservice training) in-training does seem to have a positive effect on both attitudes and practices consonant with the communicative approach.

2. The effect of experience: Experienced teachers appear to be least favourably disposed towards communicative attitudes and practices. It may be that they are more resistant to change and find it harder to reconcile new theory with their own practical experience of the classroom reality, namely they enjoy the normal. More future in-service training based on trainees' needs and a careful examination and knowledge of in-service teachers' classroom practical realities specifically targeted at experienced teachers might be necessary.

3. The effect of subject matter knowledge: specialist teachers appear to be more willing to adopt communicative views and practices than non-specialist teachers. This may, in part, be because they are more

\section{4}

J ournal of Arabic Studies in Education \& Psychology ( ASEP ) 
proficient in English and better able to cope with students' responses; non-specialists may be more dependent on set routines and exercises with predetermined answers. Hence, in-service teacher training and licensing should target working teachers' knowledge of subject matter.

\section{Table (3): Differences in Attitudes of In-service EFL Teachers Due to Teaching Experience}

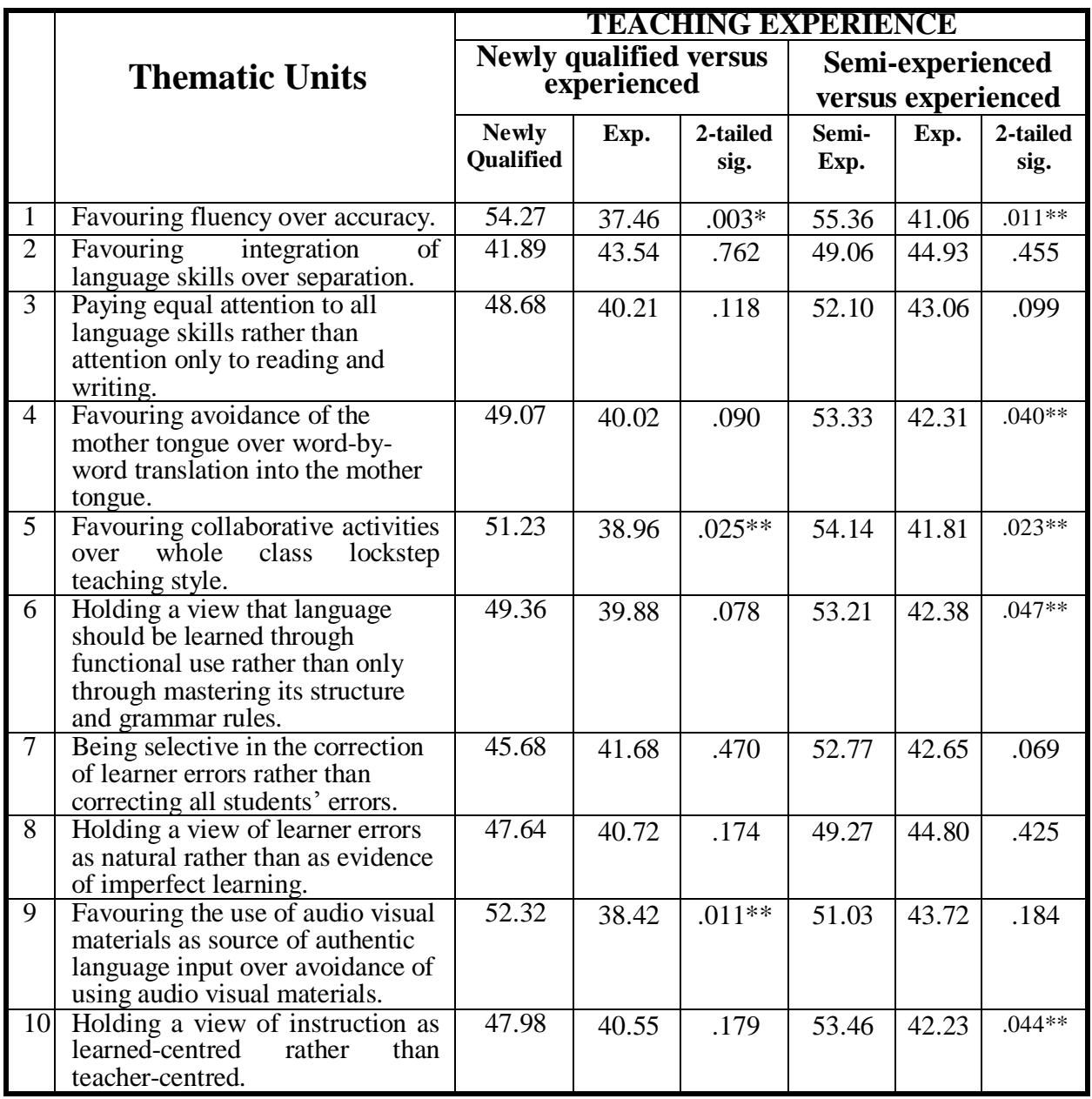

$*(P<.01) \& * *(P<.05)($ Note: Exp. $=$ Experienced. $)$ 
Table (4):Differences in Attitudes of In-service EFL Teachers due to InService Training

\begin{tabular}{|c|c|c|c|c|}
\hline & \multirow[t]{2}{*}{ Thematic Units } & \multicolumn{2}{|c|}{$\begin{array}{l}\text { IN-SERVICE } \\
\text { TRAINING }\end{array}$} & \multirow[t]{2}{*}{$\begin{array}{l}\text { 2-tailed sig. } \\
(* p<.01)\end{array}$} \\
\hline & & Trained & Untrained & \\
\hline 1 & Favouring fluency over accuracy. & 62.72 & 56.38 & .335 \\
\hline 2 & $\begin{array}{l}\text { Favouring integration of language skills } \\
\text { over separation. }\end{array}$ & 61.85 & 57.99 & .547 \\
\hline 3 & $\begin{array}{l}\text { Paying equal attention to all language skills } \\
\text { rather than attention only to reading and } \\
\text { writing. }\end{array}$ & 60.05 & 61.33 & .839 \\
\hline 4 & $\begin{array}{l}\text { Favouring avoidance of the mother tongue } \\
\text { over word-by-word translation into the } \\
\text { mother tongue }\end{array}$ & 63.60 & 54.74 & .153 \\
\hline 5 & $\begin{array}{l}\text { Favouring collaborative activities over } \\
\text { whole-class lockstep teaching style. }\end{array}$ & 58.99 & 63.30 & .497 \\
\hline 6 & $\begin{array}{l}\text { Holding a view that language should be } \\
\text { learned through functional use rather than } \\
\text { only through mastering its structure and } \\
\text { grammar rules }\end{array}$ & 62.88 & 56.08 & .280 \\
\hline 7 & $\begin{array}{l}\text { Being selective in the correction of learner } \\
\text { errors rather than correcting all students' } \\
\text { errors }\end{array}$ & 62.18 & 57.38 & .458 \\
\hline 8 & $\begin{array}{l}\text { Holding a view of learner errors as natural } \\
\text { rather than as evidence of imperfect } \\
\text { learning. }\end{array}$ & 58.93 & 63.42 & .457 \\
\hline 9 & $\begin{array}{l}\text { Favouring the use of audio visual aids as } \\
\text { source of authentic language input over } \\
\text { avoidance of using audio visual materials. }\end{array}$ & 67.37 & 47.74 & $.002^{*}$ \\
\hline 10 & $\begin{array}{l}\text { Holding a view of instruction as learned- } \\
\text { centred rather than teacher-centred. }\end{array}$ & 63.39 & 55.13 & .202 \\
\hline
\end{tabular}

\section{Findings of the Semi-Structured Interview Analysis} Research Question No. (2): What are the constraints that act against a successful application of the communicative approach in the Egyptian EFL context?

Based on informants' responses, data related to the constraints that act against the successful application of a communicative pedagogy were categorized and classified. For purpose of presentation, constraints are considered in two main categories:(1)intrinsic and (2) extrinsic constraints . Intrinsic constraints represent those factors that come from 
within teachers themselves, such as poor subject knowledge, misconceptions, etc. Extrinsic constraints refer to factors that come from without, namely, structural and organizational factors, which teachers have no control over like students and parents' expectations and attitudes, lack of resources or administrative obstacles, role of examinations, etc. Analysis also indicated that extrinsic constraints far outweighed intrinsic constraints. Extrinsic factors came into two categories: structural constraints and interpersonal constraints. Structural constraints refer to factors like, lack of time, lack of access to audio visual aids, low pay, large class size, classroom furniture layout, examination pressure, clashing requirements of both the teaching syllabus and the examination syllabus. Interpersonal constraints refer to influence of the persons with whom teachers contact such as students' attitudes, parents' expectations, school policy and administration, role colleagues, etc.

The two sets of constraints are not independent, but interdependent as shown by Figure (3) below. The interview data permits an analysis of how these types of constraints affect teachers' lives and practices and how they militate against successful implementation of the communicative approach

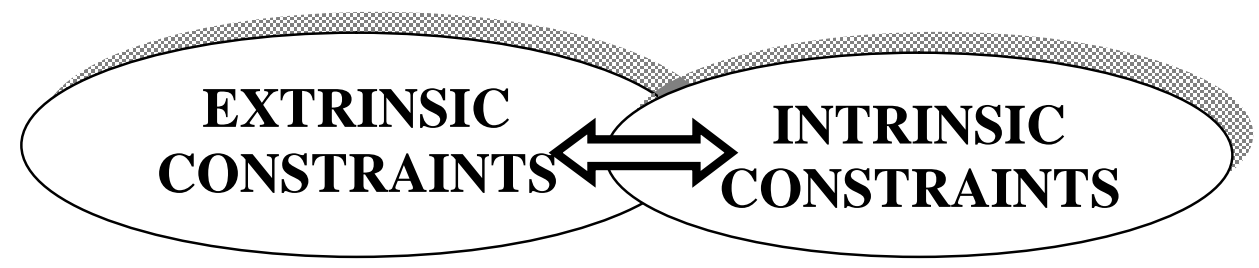

Figure (3): Interdependence between Intrinsic and Extrinsic Constraints

\section{7}

Journal of Arabic Studies in Education \& Psychology ( ASEP )

PDF created with pdfFactory Pro trial version www.pdffactory.com 


\section{Vol.2 .. No.1.. January 2008}

\section{Extrinsic Constraints}

\section{Large Class Size}

'Large class size' was reported to have a hampering influence on the organization of communicative classroom activities like group work activities. Teacher (E) commented :

"If I use group work, the group should not be more than four or five students. How can I do this within this atmosphere? Doing group work is impossible in my class"(T/E).

Teachers stated that they prefer to manage their classrooms in a lockstep style, namely, in a whole-class teacher-centred manner, something which is against establishing a learner-centred classroom atmosphere. This is because "the number of students is quite big. I can't move around quite easily like a class for boys" (T/M).

Besides, student-teacher rapport is hampered and limited in a large class. For example, one teacher commented that in a large class, 20 or 25 students understand and the others do not. Also, instead of establishing a co-operative atmosphere in the classroom, a more competitive atmosphere becomes dominant (T/J). Also, students sitting at the front usually take most of the teacher's attention. One comment said; "I can only remember names of those sitting in front of me" (T/I).

Additionally, large class size was reported to act against group work activities, and against students' participation, both of which are main principles of the communicative approach. 'It makes the students feel that the class itself is tedious and that they are not attended to by the

\section{8}

J ournal of Arabic Studies in Education \& Psychology ( ASEP ) 
teacher' (T/F).

Teachers' error correcting strategies are also affected. One teacher said: "Instead of using peer evaluation, I correct errors by myself" $(T / K)$. Also, teachers in large classes tend to "manage the classroom from the blackboard [the front of the classroom]. Besides, how can the teacher move around to guide and monitor the groups where there is no space for him to stand?" (T/D).

Large class size represents more workload on the teachers' shoulders. For example, teacher (E) complained about the amount of written work she has to correct for 200 students in the five classrooms. Acting differently, teacher (N) asked students to correct their workbooks by themselves, whereas teacher (I) mentioned that because of the large amount of written work correction, he writes a model answer on the blackboard and asks students to correct themselves in the light of the model provided.

Using audio aids such as cassettes is considered impossible in a large class despite their availability, in some cases. "If they are used, there will be lots of noise in the class. This is not a mistake in the cassettes themselves, but the mistake here is that the number of students is too large" (T/I).

\section{Economic Factors}

Economic constraints include low pay, lack of resources, large-sized unequipped classrooms, and lack of appropriate teacher training provision. In some cases the limited resources available made it difficult for teachers to prepare and present the teaching materials in line with communicative principles. One teacher commented, '...there's not even one OHP in the whole school' whilst

\section{9}

J ournal of Arabic Studies in Education \& Psychology ( ASEP ) 
another noted that:

"... there is no photocopying here. We do it outside the school. It is very expensive. I have never been allowed into the computer room. It is always closed as you saw" (T/G).

Consequently, the teacher-student rapport is badly affected since "20 or 25 students understand and the others do not. The students sitting in the front rows can understand easily" (T/N), and hence, it proves difficult to establish a good relationship with students in the back row who "prefer to keep themselves out of the picture" (T/I). Likewise, using audio visual materials and aids in large classes is hampered as "there will be lots of noise in the class. It is a waste of time sometimes. This is not a mistake in the cassettes themselves, but the number of the students is too large" $(T / O)$.

Another symptom of the economic problem is low pay, which makes teachers go for private lessons that act against the teacher's willingness to use group work. One teacher said; "Every student knows the answer, Ali knows the answer, Ahmed knows it, Hassan knows it. I cannot make them a group. It is a waste of time. You know...private lessons" (T/A). Another teacher says:

"I got students who take private lessons, you know, the clinic, and those who don't. If I go for those who take, I will be having two classes in the classroom. So, I prefer to add more clues for the students who don't know" (T/B).

\section{Examination Pressure}

The pressure exerted by parents, students, headmasters, and inspectors on teachers related to examinations is enormous. Exam results are the embodiment of learning for parents and

\section{0}

Journal of Arabic Studies in Education \& Psychology ( ASEP )

PDF created with pdfFactory Pro trial version www.pdffactory.com 
for inspectors and an evidence for the teacher's work. Besides, exam formats are not tuned to the teaching syllabuses. This makes the teacher and the student focus more upon passing form-based examinations than on communicative ability:

'The parent won't come to me at the end of the year and ask me how much his or her son can use English, but rather he will ask me: "What is the mark?' (T/G).

Another notes:

'Everyone wants his son or daughter to be the best in the exam. It is a war. It is the degree or the mark in the exam that counts' (T/M).

Pressured by parents, teachers are sensitive to parents' criticisms of their practices:

'When I used the cassette, some parents came to me and complained that their children could not write words well. Fancy what he said... "My son won't be asked to listen or speak in the exam paper' $(T / G)$.

Furthermore, teaching performances are evaluated by the inspectors based on language proficiency, ability to demonstrate language points, to use the blackboard, and to discipline the classroom. However, they are not evaluated on effective implementation of the communicative approach.

\section{The Requirements of the Annual Report on Teacher's Performance}

'I don't like to lose my future career. Every year I get 'excellent' estimation, so my results should be better year after another. I mean, I have to keep it up' (T/C). This pressure makes teachers sacrifice the ideals of the teaching syllabus in order to maintain public accountability.

\section{1}

J ournal of Arabic Studies in Education \& Psychology ( ASEP )

PDF created with pdfFactory Pro trial version www.pdffactory.com 


\section{Role of Culture}

It is deeply-rooted in Egyptian cultural traditions that students avoid expressing their views for fear of losing face or offending others. Group work discussion, for example, may be less fruitful because of students' and teachers' negative attitudes towards group work. One relevant comment is:

"I tried once or twice to do group work as the book says but I found that I could not control the class. They think it is play. They are not used to it". (T/C).

Culturally, some Egyptian values discourage students' oral communication, whether in the mother tongue or in the foreign language class. Proverbial examples include 'Who talks errs'; "A man should be responsible for his words'; and "Keep your mouth shut but your eyes and ears open". Moreover, the traditional cultural image of the teacher matches poorly with the view of the teacher in the communicative approach. Teachers, seen as knowledge holders, might consider that if they play games with students or ask students to role-play in class, they might not be seen as doing their job. Teachers are too authoritative to be challenged and so, students are not in a position to argue: they are to be obedient and learn by rote. This makes students feel uncomfortable when asked by the teacher to participate in a dialogue. The prophetic image of the teacher reinforces this authority, acting against having a good rapport between teachers and students.

\section{Colleagues}

Some teachers perceived a dissonance between the teaching styles recommended by the communicative approach and dominant teaching styles in other disciplines.

"Teachers of Arabic do not pay attention to teaching language for communicative purposes or to how the

\section{2}

J ournal of Arabic Studies in Education \& Psychology ( ASEP ) 
students should behave in different situations using different language functions." (T/B)

"Teachers of social studies, for example, do not use group work or even pair work in their classes. Teaching English is quite different. When I use group work, students feel it is a kind of play and waste of time." (T/E)

This dissonance makes it difficult for EFL teachers to introduce innovations that may be at odds with students' experiences elsewhere in the curriculum. It also highlights the role of students' learning preferences and its impact on teachers' teaching styles.

\section{Intrinsic constraints}

\section{Teachers' Academic Abilities}

In Egypt, a considerable percentage of the EFL teaching force are non-specialist and lack both proficiency and pedagogy needed for teaching EFL. In addition, the methodology component of EFL teacher education is quite shallow. Consequently, most classroom teachers do not fully understand the principles of the communicative approach in practice. One interviewee, when asked about the communicative approach advocated in the textbook said: "What do you mean? I've never heard this word [the communicative approach] before". Another teacher tellingly referred to it thus: "The communicative method, as you said..." (T/N).

Teachers have been isolated from learning theory and know little of the intellectual developments that have produced these changes in classroom approaches. Practical pedagogic understanding of the communicative approach appears to be somewhat unsure.

\section{3}

J ournal of Arabic Studies in Education \& Psychology ( ASEP ) 


\section{Feelings of Frustration and Stress}

Teachers expressed feelings of frustration and stress at the inconsistent expectations placed upon them, and at the clashing requirements of the teaching and the examination syllabi, not to mention the lack of a morally supportive work context. Such things contribute to these feelings of stress and frustration, especially because of absence of reward system. "They [school administration] don't come at the end of the year and say O.K you got the best results. You deserve an honorary gift' $(T / G)$.

Feeling constantly stressed, teachers do not have the time or freedom to design and introduce communicative classroom activities that help to motivate students towards viewing and experiencing English as a means of communication and its importance as a world language.

\section{Discussion of Findings}

Although the majority of respondents in the TACAS sample showed mildly favourable to favourable attitudes towards the communicative approach, the study points to some difficulties in the implementation of communicative methodology for EFL teaching in Egypt. In the TACAS, respondents' internal inconsistency suggests an uncertain understanding. This finding is similar to that obtained by Karavas-Doukas' (1993) study on EFL secondary school teachers in Greece, which also found that teachers tended to tick both negative and positive statements, something which Karavas-Doukas ascribed to uncertain understanding and internal inconsistency. The interviews indicated that some teachers are familiar with the communicative approach in theory but are less sure about its practicability in the classroom situation. On one level, this is not surprising, as

\section{4}

\section{J ournal of Arabic Studies in Education \& Psychology ( ASEP )}


the communicative approach in Egypt is still relatively new; however, the findings do indicate significant features related to curriculum innovation. A more detailed description of some of the most significant themes that arose from the interviews follows.

\section{- The Importance of Context}

The findings of this study indicate that teachers' attitudes are situated in particular physical and social contexts. This coincides with Putnam and Borko (2000:4). Likewise, in the Chinese context, Li (1999) found that teachers' adopt their pedagogies based on their epistemological attitudes and beliefs and occupational ideology. In this study, this perspective is confirmed by the significant differences found amongst respondents due to their specialization, teaching experiences, and in-service training and by the many ways in which practical and cultural constraints hampered teachers' ability or willingness to adopt the communicative pedagogy. Unless policy makers seriously consider how the context in which teachers teach enables them to introduce communicative teaching strategies, the quality of teaching materials and teacher training will have little impact. This consideration ranges from the straightforward check that strategies recommended are practically possible to the more complex issue of changing the beliefs and attitudes of teachers who have already had a long career using a cocktail of alternative methodologies.

The study findings concur with those well documented in the wider research on the transferability of ELT curricular innovation. The literature indicates that different constructions of meaning exist across cultures,

\section{5}

J ournal of Arabic Studies in Education \& Psychology ( ASEP ) 


\section{Vol.2 .. No.1.. January 2008}

which inhibit the transferability of particular pedagogical practices between them. For example, Orton's - in Li (1999) - stated that a methodology course based on the communicative approach could not be accepted in China unless a change is made not only in behaviours, but also in the value system of the Chinese participants. A study by Ellis (1994) in Vietnam found that the methodology course did not work with the Vietnamese learners, as it was culturally inappropriate. Teachers in the present study felt constrained by the cultural values which position the teacher as a figure of authority, who should be obeyed and whose primary responsibility is to transmit knowledge. Within this context, group work and learner-centred activities are difficult to introduce.

\section{- The Need for Synchrony in Policy and Practice}

One repeated theme is the clash between the teaching syllabus and the examination syllabus, causing a mismatch between the educational thrust of communicative classroom teaching which values spoken fluency and communication and the examinations, which assess accuracy in reading and writing. Another clash exists between the syllabi and the classroom or school reality. This, in turn, creates the pressure of accountability to parents and public bodies and directly militates against wholehearted implementation of the communicative approach. The gap between theory and practice reiterated in research studies conducted worldwide (e.g. Flores and Shiroma 2003; Karavas-Doukas, 1993 \& 1996; Al Hamzi, 2003; Li, 1998; Raharjo, 1988; KaravasDoukas, 1996; Siahaan, 1998; Mulat, 2003; Butler, 2005; Razmjoo and Riazi, 2006; Abd Al-Magid, 2006; etc.). For example, in Chile the gap between theory and practice

\section{6}

\section{J ournal of Arabic Studies in Education \& Psychology ( ASEP )}


between universities and schools and the lack of a clear framework of what it means to teach nowadays, emerge as the major weaknesses of current initial teacher education programmes (Flores and Shiroma 2003). In the Greek EFL context, Karavas-Doukas' (1993) study of secondary school teachers' attitudes towards the communicative approach discovered a gap between teachers' attitudes towards the communicative approach and their actual classroom practices. She also discovered a gap between the teaching syllabus and the examination syllabus.

\section{- The Value of Training and Education}

The differences observed amongst respondents due to specialization, teaching experiences, and in-service training highlight the significant role played by teacher education, both pre-service and in-service. This result supports the previous literature in this respect (see Abdullah-Sani, 2000; Almarza, 1996; Borg, 1998a, Borg, 1998; Burns, 1996; Clandinin, 1986; Elbaz, 1983; Freeman, 1996; Gimenez, 1994; Westerman, 1991; Woods 1996; etc.).

Training courses in Egypt do appear to be a powerful mechanism for changing pedagogical practices, attitudes and beliefs and for giving teachers confidence with communicative teaching principles. However, the results related to the influence of teaching experience in this study contradict those obtained by Richards et al. (1992). Compared with experienced teachers, inexperienced teachers were more likely to favour the role grammatical theories play in language teaching. The reasons for this are not evident from this study but it is possible that these experienced teachers' beliefs, both cultural and pedagogical, are more deeply rooted in traditional teaching methods than

\section{7}

\section{J ournal of Arabic Studies in Education \& Psychology ( ASEP )}


younger and less experienced teachers. It is also possible that in-service training courses for these teachers are not appropriately targeted at their level of experience. These teachers may be less impressed by teaching recommendations which clearly do not translate to their classroom contexts (such as pair work in large classes) than teachers with less practical classroom experience.

\section{Conclusion}

The findings of this study offer a clear message for policy makers, curriculum developers and teacher educators in Egypt. Holliday (1994) and Hargreaves (1998) have argued for policymakers to take into account the fact that teacher knowledge, beliefs, attitudes and contexts influence their teaching'. Also, Louden (1991: iv) has made it clear that " teachers don't merely deliver the curriculum. They develop it, define it and reinterpret it too". This study highlights the importance of ensuring that teachers are introduced to new methodological principles and above all that the contexts in which they work are acknowledged. This means that teacher educators need to be informed about the social context in which teachers operate. "Leaving such information out may limit teachers' opportunities to understand and or resist forces that strongly influence what it is like to work as a teacher". (Hatch, 1999:230). Besides, since teacher education programmes are of course deeply influenced by the wider context in which they are situated, they need to reflect their own contextual reality rather than merely importing ideas off-the shelf from other parts of the world (Wedell, 2004).

In the same vein, novice EFL teachers emerging from even the most ideal initial teacher training programme will

\section{8}

J ournal of Arabic Studies in Education \& Psychology ( ASEP ) 
have a shock as they move into the world of full time teaching in what will usually be an unfamiliar school environment. They will frequently encounter problems resulting from lack of coherence between components of the TESOL micro environment, which may affect learners' motivation, the ease with which particular teaching-learning techniques can be introduced, the attitudes of older colleagues/school administrators, parental expectations. In this respect, inspectors of teachers and in-service teacher training should address, as part and parcel of the training process itself, how teachers can manage using applying the ideals of training with the available resources. The more teachers can be supported for their first few years of teaching, the more likely they are to be willing and able to try to be the best teachers they can be, even in less than ideal circumstances. Establishing novice teacher support mechanisms is thus an integral part of any significant change to the EFL teacher education curriculum. The case is similar in Chile. Yet, the existing teacher networks and the introduction of school-based mentors with responsibilities for novice teachers show what can be done. However if these are to maximise their beneficial effects, time and space for teachers to meet needs to be made regularly available within existing school timetables, teachers need to be supported by school principals and be seen as part of normal professional activity, rather than something extra to be squeezed in (Leithwood, 2002, Harris, 2003, Harvey, 1996, Fullan, 2000).

"Educational policy of any country is driven by different priorities which are dependent on the social, political, cultural and economic context within which they

\section{9}

\section{J ournal of Arabic Studies in Education \& Psychology ( ASEP )}


are embedded" (Flores and Shiroma, 2003:6). In EFL countries, such as Egypt, English curriculum aims and the manner in which these are translated into outcomes, need to be adjusted to meet the realities of the contexts in which they are embedded. TEFL teacher education programmes then need to be designed and carried out to help meet these realistic outcomes.

Such reconceptualizations of curriculum aims and outcomes and the development of TEFL teacher education programme that will support them will require sustained work over a time span. This implies that "educational change needs to be seen as a state not a government issue, with the provision of economic and political support over time" (Cox and Le Maitre, 1999) and that "governments must put educational investment beyond their own need for political survival" (Fullan, 2001:233).

Unless the examination system is in synchrony with the advocated teaching system, the former will always impede innovation in the latter. Moreover, a curriculum change whatsoever must take into account the potentialities of both classroom and school ecologies. Without coherence between the different dimensions of curriculum innovation process, no development whatsoever can be expected. What makes matters worse, teachers living and experiencing that state of disparity will feel alienated and detached from their own world.

The findings of the study related to the gap between theory and practice helps to attract curriculum developers' attention to the well-established fact that teachers do not passively accept innovative ideas once they have been informed about them. Namely, they will not accept

\section{0}

\section{J ournal of Arabic Studies in Education \& Psychology ( ASEP )}


innovation unless they are convinced of their effectiveness. In other words, teachers accept, misinterpret or reject the innovative ideas based on the compatibility/incompatibility of these ideas with their existing pedagogical values or attitudes. This should be considered by syllabus and textbooks developers. To assume that teachers hold robotic schemata that can be tuned by educational authorities once they want to is naïve and self-deceiving. Through illuminating the ELT context, this study emphasizes that good intentions do not guarantee good results. A particular curriculum philosophy does not induce change in practice unless its implementers are aware of it and able to assimilate it into their belief systems and make it their own.

The study's findings brought to the surface the impact of both types of intrinsic and extrinsic constraints. Hence, further research studies are needed to investigate the role of each type of constraints and the impact of the individual constraints in each type in the process of language teaching and learning. This is because good diagnosis is a priori step in good treatment. An exploration of the impact of these individual constraints helps to bridge the gap between theory and practice.

The study's findings are based on teachers' responses to the TACAS and their articulation of the constraints facing the adoption of a more communicative classroom pedagogy in their teaching. In this respect, further research studies are required to ascertain the extent to which teachers' espoused favourable attitudes (i.e. theories) towards the communicative view of language teaching and learning are put into practice. This can be achieved through action research studies to observe the extent to which EFL teachers' act upon their espoused theories and the constraints acting in

\section{1}

\section{J ournal of Arabic Studies in Education \& Psychology ( ASEP )}


between theory and practice.

Finally, if we are serious about wanting to see changes in both the processes and the outcomes of our national English language teaching system, we have no real choice but to try to ensure that our teacher education programmes (both pre-service and in-service) prepare teachers to help learners to achieve these outcomes, since "Educational change depends on what teachers do and think, it is as simple and as complex as that" (Fullan, 2001:115).

\section{References}

1. Abd Al-Magid, M. A. (2006). The effect of Teachers' Attitudes on the Effective Implementation of the Communicative Approach in ESL Classrooms, Unpublished Master of Arts, University of South Africa $<\underline{\text { http://etd.unisa.ac.za/ETD-db/ETD- }}$ desc/describe?urn=etd-06272007-151534>(Retrieved on $1 / 1 / 2008$ ).

2. Abdullah-Sani, S. A. Z. (2000). An analysis of the development of teacher belief constructs during teaching practice and in the novice year of teaching: A case study of English language teachers in the Malaysian context. Unpublished $\mathrm{PhD}$ thesis, University of Warwick, UK.

3. Al-Hamzi, S. (2003). EFL teacher preparation programmes in Saudi Arabia: Trends and Challenges. TESOL Quarterly, 37(2):341-345

4. Almazra, G. (1996). Student foreign language teachers' knowledge growth. In D. Freeman and J. C. Richards (eds.) Teacher learning in language teaching (pp.50-78). Cambridge: Cambridge University Press.

5. Anderson, J. (1993). Is a communicative approach practical for teaching English in China? Pros and cons. System, 21(4): 471480.

6. Bahaa Eddin, H. (1991). Mubarak and Education. Cairo: Rozalyousif.

\section{2}

J ournal of Arabic Studies in Education \& Psychology ( ASEP )

PDF created with pdfFactory Pro trial version www.pdffactory.com 
7. Bogdan, R. C. and Biklen, S. K. (1992). Qualitative Research for Education ( $2^{\text {nd }}$ ed.). Needham Heights, MA. Allyn and Bacon.

8. Borg, S. (1998). Teacher Cognition in Second Language Grammar Teaching. Unpublished $\mathrm{PhD}$ thesis, University of Exeter.

9. Borg, S. (1998). Teachers' pedagogical systems and grammar teaching: A qualitative study. TESOL Quarterly, 32(1): 9-38.

10. Burns, A. (1996) Starting all over again: From teaching adults to teaching beginners. In D. Freeman and J.C Richards (eds.) Teacher learning in language teaching (pp.154-177). Cambridge: Cambridge University Press.

11. Butler, Y. G. (2005). Comparative perspectives towards communicative activities among elementary school teachers in South Korea, Japan and Taiwan. Language Teaching Research, 9(4): 423-446.

12. Clandinin, D. J. (1986). Classroom Practice: Teacher Images in Action, London and Philadelphia: The Falmer Press.

13. Cook, B. J. (1998). Doing educational research in a developing country: reflections on Egypt. Compare, 28(1): 93-103.

14. Cook, V.J. (1991). Second Language Learning and Language Teaching. London: Edward Arnold.

15. Cox, C. and Le maitre, M. J. (1999). Market and State Principles of Reform in Chilean Education: Policies and Results in G. Perry and D. Leipziger (eds.) Chile: Recent Policy Lessons and Emerging Challenges. Washington. World Bank Institute of Development Studies.

16. Elbaz, F. L. (1983). Teacher Thinking: A Study of Practical Knowledge. London: Croom Helm.

17. Ellis, G. (1994). How culturally appropriate is the communicative approach? ELT Journal, 50(3): 213-218.

18. Flores M. A. and Shiroma, E. (2003). Teacher professionalisation and professionalism in Portugal and Brazil: what do the policy documents tell? Journal of Education for Teaching, 29(1): 5-18

19. Freeman, D. (1996). Renaming experience/ reconstructing practice: Developing new understandings of teaching. In D.

\section{3}

Journal of Arabic Studies in Education \& Psychology ( ASEP ) 
Freeman and J. C. Richards (eds.) Teacher Learning in Language Teaching (pp.221-241). Cambridge: Cambridge University Press.

20. Fullan, M. G. (1993). Change Forces: Probing the Depths of Educational Reform. London: Falmer Press.

21. Fullan, M. G. (2001). The New Meaning of Educational Change ( $3^{\text {rd }}$ Edition). London: Cassell.

22. Gimenez, T. N. (1994). Learners Becoming Teachers: An Explanatory Study of Beliefs Held by Prospective and Practicing EFL Teachers in Brazil. Unpublished PhD thesis, University of Lancaster.

23. Glasser, B. G. and Strauss, A. L. (1976). The Discovery of Grounded Theory. Chicago: Aldane.

24. Hargreaves, A. (1998). Pushing the boundaries of educational change. In Hargreaves, A., Lieberman, A., Fullan, M., Hopkins, D. (eds.) International Handbook of Educational Change (pp.281-296). Dordrecht: Kluwer Academic Publishers.

25. Hargreaves, E. (1997). The diploma disease in Egypt: Learning, teaching and the monster of the secondary leaving certificate. Assessment in Education 4(1): 161-176.

26. Harmer, J. (1983). The Practice of English Language Teaching. Essex: Longman.

27. Harris, A. (2003). Behind the classroom door: the challenge of organisational and pedagogical change. Journal of Educational change, 4(4): 369-382

28. Harvey, S. P. (1996). Primary Science INSET in South Africa: An Evaluation of Classroom Support. Unpublished $\mathrm{PhD}$. University of Exeter UK.

29. Hatch, J.A. (1999). What preservice teachers can learn from studies of teachers' work, Teaching and Teacher Education, 15(3): 229-242.

30. Holliday, A. (1994). Appropriate Methodology and Social Context. Cambridge: Cambridge University Press.

31. Horwitz, E. K (1988). Using student beliefs about language learning and teaching in the foreign language methods course. Foreign Language Annals, 18(4): 333-340.

32. Hymes, D. (1972). On Communicative Competence. In J.B. 
Pride and J. Holmes (eds.) Sociolinguistics (pp.269-293) Harmondswortth: Penguin.

33. Johnson, K. and Morrow, K. (1981). Communication in the Classroom: Applications and Methods for a Communicative Approach. Essex: Longman.

34. Johnson, K. E. (1992). The relationship between teachers' beliefs and practices during literacy instruction for non-native speakers of English. Journal of Reading Behaviour, 24(1): 83108.

35. Johnson, S., Monk, M. and Swain, J. (2000). Constraints on development and change to science teachers' practice in Egyptian classrooms', Journal of Education for Teaching, 26(1): 9-24.

36. Karavas-Doukas, E. (1993). English Language Teachers in the Greek Secondary School: A Study of their Classroom Practices and their Attitudes towards Methodological and Material Innovation. Unpublished $\mathrm{PhD}$ thesis, University of Warwick.

37. Karavas-Doukas, E. (1996). Using attitude scales to investigate teachers' attitudes to the communicative approach. English Language Teaching Journal, 50(3): 187-198.

38. Leithwood, K. Jantzi, D. and Mascall, B. (2002). A Framework for Research on large scale reform. Journal of Educational Change, 3(1): 7-33.

39. Li, D. (1998). "It's always more difficult than you plan and imagine": Teachers' perceived difficulties in introducing the communicative approach in South Korea. TESOL Quarterly, 32(4): 677-703.

40. Li, M. S. (1999) Conflicts in teacher-student role beliefs and expectations: A study of expatriate teachers teaching English in China. The weaver: A forum for new ideas in education. <http://www.latrobe.edu.au/www/grade/MSLed3.ht ml> (Retrieved on 19/12/07).

41. Littlewood, W. (1981). Communicative Language Teaching: An Introduction. Cambridge: Cambridge University Press.

42. Louden, W. (1991). Understanding Teaching: Continuity and Change in Teachers' knowledge. New York: Teachers College Press.

43. Markee, N. (1994). Curricular innovation: Issues and problems,

\section{5}

Journal of Arabic Studies in Education \& Psychology ( ASEP ) 
Applied Language Learning, 5(2): 1-30.

44. Markee, N. (1997). Managing Curriculum Innovation. Cambridge: Cambridge University Press.

45. Miles, M. B. \& Huberman, A. M. (1994). Qualitative Data Analysis. Second edition. London: Sage Publications.

46. Millar, N. (1989). The implications of a communicative approach for language teacher education: preliminary projects carried out in Norwegian teachers' colleges. European Journal of Teacher Education, 12(2): 151-157.

47. Mulat, L. (2003). Teachers' Attitudes towards Communicative Language Teaching and Practical Problems in its Implementation. Unpublished Master of Arts in Teaching English as a Foreign Language (TEFL), Addis Ababa University, < $\quad$ http://hdl.handle.net/123456789/673> (Retrieved on 01/01/2008).

48. Nunan, D. (1989a). Designing Tasks for the Communicative Classroom. Cambridge: Cambridge University Press.

49. Nunan, D. (1989b). Understanding Second Language Classrooms. London: Prentice Hall.

50. Nunan, D. (1995a). Closing the gap between learning and instruction, TESOL Quarterly, 29(1): 133-158.

51. Nunan, D. (1995b). Contextual factors in determining appropriate language methodologies. In R. Budd, (ed.) The Journal: Appropriate Methodology: from Classroom Methods to Classroom Processes (pp.15-25). Paris: TESOL France and the British Council.

52. Oatey, H. (1984). Teacher training in the People's Republic of China: A case report. Language Learning and Communication, 3(3): 353-365.

53. Raharjo, I. (1988). Teaching Indonesian as a Foreign Language in the A.C.T Using the Communicative Approach, Australasian Digital Theses Program.

54. Razmjoo, S. A. and Riazi, A. M. (2006). Is Communicative Language Teaching Practical in the Expanding Circle?: A Case Study of Teachers of Shiraz High Schools and Institutes? Journal of Language and Learning, 4(2): 144-171.

55. Richards, J.C. \& Rodgers, T.S. (2006). Approaches and

\section{6}

J ournal of Arabic Studies in Education \& Psychology ( ASEP ) 
Methods in Language Teaching. Cambridge: Cambridge University Press.

56. Richards, J.C. P. Tung, and P. Ng (1992). The culture of the English language teacher: A Hong Kong example. RELC Journal, 23(1): 81-102.

57. Richardson, V. (1996). The role of attitudes and beliefs in learning to teach. In J. Sikula, T. Buttery and E. Guyton (eds.) Handbook of Research on Teacher Education (pp.102-119). New York: Macmillan.

58. Siahaan, R. (1998). Teachers' Perceptions of the Communicative Language Teaching Approach in a Teacher Training Program in Indonesia, Unpublished MA Thesis, University of Canberra, Canberra.

59. The Egyptian Society for Development and Childhood and the Ministry of Education (1993). The National Conference for Developing Primary Education-the final report for the conference preliminary workshop. Cairo: NCERD.

60. The Egyptian Society for Development and Childhood and the Ministry of Education (1996). The National Conference for Developing Preparatory Education-the final report for the conference preliminary workshop. Cairo: NCERD.

61. Topper, A. G. (1999). Conversations about Teaching and Technology: A Technology Support Group for Teacher Professional Development. Unpublished $\mathrm{PhD}$ thesis, Michigan State

University.

$<$ http://www.edu.msu.edu/homepages/topper/AREASessions2 3-25.htm> (Retrieved on 19/12/07).

62. Walsh, D. J., Tobin, J. J. and Graue, E. M. (1993). The interpretive voice: qualitative research in early childhood. In B. Spodek (ed.). Handbook of Research on the Education of Young Children (pp.264-267). New York and London: Macmillan.

63. Westerman, D. A. (1991). Expert and novice teacher decisionmaking. Journal of Teacher Education, 42(4): 292-306.

64. Woods, D. (1996). Teacher Cognition in Language Teaching. Cambridge: Cambridge University Press.

\section{7}

J ournal of Arabic Studies in Education \& Psychology ( ASEP ) 


\section{Appendix (1)}

\section{Teachers' Attitudes towards the Communicative Approach Scale (TACAS)}

Please put a tick [, ] where appropriate

Section one: Background Information

1- GENDER Male $q$ Female $q$

2- AGE 20-24 q $25-29$ q 30-34 q 35-39 q 40-44 q

3- A. QUALIFICATION(s)

a) BA in Education and English, Faculty of Education

b) BA in English literature, Faculty of Arts

c) B. BA in Psychology, Faculty of Art

d) BA in Philosophy and Sociology, Faculty of Education ( )

e) Others, (please, specify).................................

4- Years of experience as a teacher of English at the preparatory school:

Up to 5 q $\quad 6-10$ q 11 or more years $q$

5- Did you attend in-service training on teaching preparatory English?

$$
\begin{array}{lll}
\text { Yes } & \text { No } \\
&
\end{array}
$$

Section two: Teacher Attitudes towards the Communicative Approach Scale

Please respond to each of the following statements in the table by putting a tick [, ] where you think appropriate. $\mathrm{S}=$ Strongly agree, $\mathrm{A}=$ Agree, $\mathrm{U}=$ Undecided, $\mathrm{D}=$ Disagree and $\mathrm{SD}=$ Strongly disagree.

\section{8}

\section{J ournal of Arabic Studies in Education \& Psychology ( ASEP )}

PDF created with pdfFactory Pro trial version www.pdffactory.com 
Vol.2 .. No.1.. January 2008

\begin{tabular}{|c|c|c|c|c|}
\hline & $\begin{array}{c}\text { STATEMENTS } \\
\text { The English language teacher should... }\end{array}$ & SA & $\mathbf{A} \mid \mathbf{l}$ & $\mathbf{D} \mid \mathbf{S D}$ \\
\hline 1 & $\begin{array}{l}\text { Focus only on language activities, which aim } \\
\text { to increase students' accuracy of the } \\
\text { language. }\end{array}$ & & & \\
\hline 2 & $\begin{array}{l}\text { Be selective in correcting learners' errors in a } \\
\text { way that does not impede comprehension and } \\
\text { communication. }\end{array}$ & & & \\
\hline 3 & $\begin{array}{l}\text { See the student more as a partner in the } \\
\text { teaching-learning process than being a } \\
\text { passive recipient of knowledge. }\end{array}$ & & & \\
\hline 4 & $\begin{array}{l}\text { Consider his/her role in the classroom as only } \\
\text { to impart information about language. }\end{array}$ & & & \\
\hline 5 & $\begin{array}{l}\text { Teach the language skills (listening, speaking, } \\
\text { reading and writing) in an integrated manner. }\end{array}$ & & & \\
\hline 6 & $\begin{array}{l}\text { Assess students' responses only in terms of } \\
\text { how grammatically correct they are. }\end{array}$ & & & \\
\hline 7 & $\begin{array}{l}\text { Encourage students to interact with one } \\
\text { another through a variety of ways (e.g. pair } \\
\text { work, role play, group work, etc). }\end{array}$ & & & \\
\hline 8 & $\begin{array}{l}\text { Use audio visual aids in class as a source of } \\
\text { authentic language input. }\end{array}$ & & & \\
\hline 9 & $\begin{array}{l}\text { Give word-by-word translation in class if } \\
\text { students are to understand. }\end{array}$ & & & \\
\hline 10 & $\begin{array}{l}\text { Stress English language structure over and } \\
\text { above all other aspects of language. }\end{array}$ & & & \\
\hline 11 & Give equal attention to all language skills. & & & \\
\hline 12 & $\begin{array}{l}\text { Correct all learners' errors on the spot lest } \\
\text { students should acquire bad language habits. }\end{array}$ & & & \\
\hline 13 & $\begin{array}{l}\text { View that language learning comes about } \\
\text { through using language communicatively } \\
\text { (functionally) }\end{array}$ & & & \\
\hline 14 & $\begin{array}{l}\text { Consider him/herself as the conductor of the } \\
\text { classroom situation determining who, when to } \\
\text { talk and what to talk about. }\end{array}$ & & & \\
\hline 15 & $\begin{array}{l}\text { Teach language skills in a discrete fashion, } \\
\text { for the purpose of mastery. }\end{array}$ & & & \\
\hline
\end{tabular}

\section{9}

J ournal of Arabic Studies in Education \& Psychology ( ASEP ) 
Vol.2 .. No.1.. January 2008

\begin{tabular}{|c|c|c|c|c|c|c|}
\hline & $\begin{array}{c}\text { STATEMENTS } \\
\text { The English language teacher should... }\end{array}$ & $\mathbf{S A}$ & $\mathbf{A}$ & $\mathbf{U}$ & $\mathbf{D}$ & $\mathrm{SD}$ \\
\hline 16 & $\begin{array}{l}\text { View that transmitting information is only } \\
\text { one of the many different roles he/she must } \\
\text { perform. }\end{array}$ & & & & & \\
\hline 17 & $\begin{array}{l}\text { Give priority in his/her assessment of } \\
\text { students' answers to whether they are } \\
\text { communicatively appropriate rather than to } \\
\text { how consistent they are with grammatical } \\
\text { rules. }\end{array}$ & & & & & \\
\hline 18 & $\begin{array}{l}\text { See learners' errors as an inevitable and a } \\
\text { natural part of learning a language. }\end{array}$ & & & & & \\
\hline 19 & $\begin{array}{l}\text { Lessen class noise and exploit the class } \\
\text { teaching time to the utmost by avoiding the } \\
\text { use collaborative activities. }\end{array}$ & & & & & \\
\hline 20 & $\begin{array}{l}\text { Avoid using L1 as much as possible by using } \\
\text { a variety of techniques such as flashcards, } \\
\text { realia, or pictures in order to facilitate pupils' } \\
\text { understanding. }\end{array}$ & & & & & \\
\hline 21 & $\begin{array}{l}\text { Give equal attention to both English language } \\
\text { structure and functions. }\end{array}$ & & & & & \\
\hline 22 & $\begin{array}{l}\text { Consider that to learn a language is only to } \\
\text { master its structure and grammar rules. }\end{array}$ & & & & & \\
\hline 23 & $\begin{array}{l}\text { Avoid using cassettes in class as it takes a lot } \\
\text { of class teaching time. }\end{array}$ & & & & & \\
\hline 24 & $\begin{array}{l}\text { Consider that the learner errors are an } \\
\text { evidence of imperfect learning. }\end{array}$ & & & & & \\
\hline 25 & $\begin{array}{l}\text { Give priority in attention to writing and } \\
\text { reading skills to prepare students for the final } \\
\text { exams. }\end{array}$ & & & & & \\
\hline 26 & $\begin{array}{l}\text { Consolidate the use of activities which aim to } \\
\text { develop the students' use of the language. }\end{array}$ & & & & & \\
\hline
\end{tabular}




\section{Appendix (2): Protocol of the Semi-Structured Interviews}

The protocol used in the semi-structured interviews addressed almost all the potential constraints teachers might face. Below is the range of questions, sub-questions and probes posed in the semi-structured interviews.

1. What are the problems that you face in your daily life? How?

- Give me an example.

- How does it affect your work in the classroom?

2. What are the constraints that you face in your daily work at school? How?

- Give me an example?

- How does it affect your work in the classroom?

- Why?

3. What are the constraints that you face when dealing with students? How?

- Give me an example?

- How does it affect your work in the classroom?

- Why?

4. What are the constraints based in the school context that affect the way you teach?

- Give me an example?

- How does it affect your work in the classroom? How?

- Why?

5. What are the constraints based outside of school that you feel affect your work in the classroom?

- Give me an example? How?

- How does it affect your work in the classroom?

- Why?

6. What are the constraints based in the classroom atmosphere that affect the way you deal with students?

- Give me an example? How?

- How does it affect your work in the classroom?

- Why?

7. What are the constraints that you face in teaching the textbook?

- Give me an example. How?

- How does it affect your work in the classroom?

- Why?

8. What are the most serious constraints that you think hamper your attempt to teaching the textbooks following a communicative pedagogy and using communicative classroom techniques?

- Give me examples how this problem affects your work in the classroom.

- Give me examples of how this problem affects you when you deal with textbooks.

- Give me examples of how this problem affects your work when you deal with students. 